\title{
Hypertension and Age-Related Cognitive Impairment: Common Risk Factors and a Role for Precision Aging
}

\author{
Meredith Hay ${ }^{1,2,3}$ (D) Carol Barnes ${ }^{2,3} \cdot$ Matt Huentelman $^{4,3} \cdot$ Roberta Brinton $^{5,3} \cdot$ Lee Ryan $^{2,3}$ \\ Published online: 3 September 2020 \\ (C) Springer Science+Business Media, LLC, part of Springer Nature 2020
}

\begin{abstract}
Purpose of Review Precision Aging ${ }^{\circledR}$ is a novel concept that we have recently employed to describe how the model of precision medicine can be used to understand and define the multivariate risks that drive age-related cognitive impairment (ARCI). Hypertension and cardiovascular disease are key risk factors for both brain function and cognitive aging. In this review, we will discuss the common mechanisms underlying the risk factors for both hypertension and ARCI and how the convergence of these mechanisms may be amplified in an individual to drive changes in brain health and accelerate cognitive decline.

Recent Findings Currently, our cognitive health span does not match our life span. Age-related cognitive impairment and preventing and treating ARCI will require an in-depth understanding of the interrelated risk factors, including individual genetic profiles, that affect brain health and brain aging. Hypertension and cardiovascular disease are important risk factors for ARCI. And, many of the risk factors for developing hypertension, such as diabetes, smoking, stress, viral infection, and age, are shared with the development of ARCI. We must first understand the mechanisms common to the converging risk factors in hypertension and ARCI and then design person-specific therapies to optimize individual brain health.

Summary The understanding of the convergence of shared risk factors between hypertension and ARCI is required to develop individualized interventions to optimize brain health across the life span. We will conclude with a discussion of possible steps that may be taken to decrease ARCI and optimize an individual's cognitive life span.
\end{abstract}

Keywords Cognitive aging $\cdot$ Hypertension $\cdot$ Risk factors $\cdot$ COVID-19 $\cdot$ Precision aging

\section{Introduction}

Precision Aging ${ }^{\circledR}$ is the application of precision medicine to the identification of the individual risk profiles and genetic

This article is part of the Topical Collection on Secondary Hypertension: Nervous System Mechanisms

Meredith Hay

mhay@arizona.edu

1 Department of Physiology, University of Arizona, 1501 N Campbell Rd, Room 4103, Tucson, AZ 85724, USA

2 Psychology Department, University of Arizona, Tucson, AZ, USA

3 Evelyn F. McKnight Brain Institute, University of Arizona, Tucson, AZ, USA

4 Neurogenomics Division, TGen, Phoenix, AZ, USA

5 Center for Innovative Brain Sciences, University of Arizona, Tucson, AZ, USA characteristics that link cognitive health span to life span. While there are many risk categories that affect brain and cognitive health, the effects of hypertension and cardiovascular disease on the development of age-related cognitive impairment (ARCI) and progression to Alzheimer's disease (AD) and AD-related dementias (ADRD) are well supported and have been recently reviewed [1•]. Importantly, many of the identified risk factors for the development of hypertension and cardiovascular disease are common to those identified for ARCI, AD, and ADRD [2••].

Previously, we have identified key drivers of brain health and disease that can be altered by the risk factors for ARCI [2••]. These drivers include brain inflammation [3, 4], compromised brain blood flow [5], increased neuropathology [6], and detrimental changes in synaptic function and synaptic connectivity [7]. Each of these drivers can be affected by known risk factors that ultimately accumulate and interact to alter neuronal function and cognition. The ultimate prevention and treatment of ARCI will require in-depth mechanistic 
understanding of how these common risk factors and risk categories interact to alter these drivers of brain health and disease.

According to the US Centers for Disease Control and Prevention and the American Heart Association [8, 9], key risk factors associated with the development of high blood pressure and secondary hypertension include chronic inflammatory diseases such as diabetes and obesity as well as environmental conditions such as high stress and smoking. An additional recent risk is contracting the SARS-COV-2 virus and complications from COVID-19 which include activation of cytokine release syndrome (CRS) which is known to result in the release of proinflammatory cytokines from macrophages and endothelial cells leading to extensive lung, heart, and vascular injury [10-12]. These risk factors are compounded by individual genetic profiles and age to increase the risk for developing hypertension. In turn, hypertension, in combination with the above listed risk factors, also results in an increased risk for cardiovascular disease and stroke [13].

Vascular contributions to cognitive impairment and dementia (VCID), AD, and ADRD significantly contribute to the 47 million people worldwide who suffer with dementia [14]. In addition, in the $87 \%$ of people over 65 years of age who are not demented [15], many of these individuals will experience ARCI that directly affects their quality of life and independence. This number is estimated to increase to over 130 million people by 2050 . A number of studies have shown that risk factors for ARCI, VCID, and conversion to AD include hypertension, cardiovascular disease, diabetes, smoking, systemic inflammation, and stress [4, 16-22].

According to a 2017 report from the Alzheimer's Association [23], the cost of Alzheimer's disease (AD) and ADRD to the healthcare system is staggering with recent estimates for both paid and unpaid care costs for people in the USA by 2050 to exceed $\$ 1.1$ trillion dollars. In addition to AD and ADRD, many older adults will also acquire age-related cognitive impairment (ARCI) that results in decreased quality of life, loss of independence, and productivity. The National Institute on Aging (NIA) has created a National Plan to Address Alzheimer's Disease in response to the 2011 National Alzheimer's Project Act. A key goal of the National Plan is to prevent and effectively treat Alzheimer's disease and ARCI by 2025. The 2019 update of this plan includes expanded support for research to identify the molecular and cellular mechanisms underlying the development of ARCI and ADRD. This review will provide an overview of the current understanding of the some of the shared molecular and cellular pathological mechanisms underlying specific risk categories common to both hypertension and ARCI including diabetes, smoking, stress, SARS-COV-2 infection, and age and how these common mechanism may be integrated, using a Precision Aging ${ }^{\circledR}$ model, to understand and affect the drivers of brain health and disease (Fig. 1).

\section{Diabetes: a Key Risk Category for both Hypertension and Cognitive Dysfunction}

Hypertension and type 2 diabetes (T2D) are often found in the same person, and there is considerable overlap in the etiology and disease mechanisms between hypertension and diabetes. Hypertension is found in nearly $30 \%$ of the adult population in the USA [24] and is present in over 78\% of persons with diabetes [25]. In the Multi-Ethnic Study of Atherosclerosis (MESA) in over 3500 participants who were not hypertensive, those with diabetes and higher resting blood glucose levels were more likely to develop hypertension over the 4.7 years of the study [26]. In the USA, individuals with T2D are 2.5 times more likely to develop high blood pressure [27]. Likewise, a number of studies have shown that the presence of high blood pressure is an independent risk factor for the development of new-onset diabetes $[6,28]$. In a study using meta-analysis from 4.1 million adults, individuals with a $20 \mathrm{mmHg}$ higher systolic blood pressure had a $52 \%$ increase in developing diabetes [6].

The cellular and molecular mechanisms shared between hypertension and T2D include insulin resistance, increased activation of the renin-angiotensin-aldosterone system (RAAS), oxidative stress, and endothelial dysfunction [29, 30]. Insulin resistance and its associated hyperinsulinemia increases oxidative stress and reactive oxygen species (ROS) production via NADPH oxidase imbalance, which increases metabolic flux of the polyol (sorbitol) pathway and increases production of advanced glycation end products (AGE), acti133vation of protein kinase $\mathrm{C}$, and others [31-33]. Likewise, increased RAAS activation, a well-known contributor to hypertension [34, 35], increases sympathetic outflow and increases vascular ROS and contributes to endothelial cell senescence, vascular aging [36••], and high blood pressure [30, 37, 38].

Sex differences in the role of diabetes in the development of hypertension and cardiovascular disease have been studied extensively over the last few decades [39], [40-43]. While both men and women exhibit age-related increases in blood pressure, premenopausal women have a lower incidence of hypertension than age-matched men $[44,45]$. After the age of 55, hypertension incidence in women markedly increases with nearly $70 \%$ of women over 65 being diagnosed with hypertension in the USA [41]. In premenopausal women, it is thought that the presence of ovarian hormones affords protection to women against the development of cardiovascular disease and hypertension [46, 47]. The mechanisms underlying ovarian hormone protection have been suggested to include estradiol-induced increases in vascular endothelial nitric oxide production and vasodilation [48], improvement in endothelial function [49], and, in the case of hypertension, estrogen-induced central inhibition of sympathetic outflow $[50,51]$. Importantly, this lower risk of hypertension in women under 55 is lost in the presence of T2D [43, 49, 52]. While 
Fig. 1 Illustration of how the shared risk categories between hypertension and age-related cognitive impairment and some of their common mechanisms including inflammatory cytokines (e.g., IL6, TNFa), oxidative stress (ROS), mitochondria dysfunction (Mito-X), and endothelial cell dysfunction (Endo-X) are combined with an individual's genetic profile to result in a specific, Precision Aging ${ }^{\circledR}$ predicted, brain health profile (some images are derived and attributed to Creative Commons CCBY 4.0)

\section{Combined Mechanisms Underlying Risks Drivers of Brain Health and Disease}
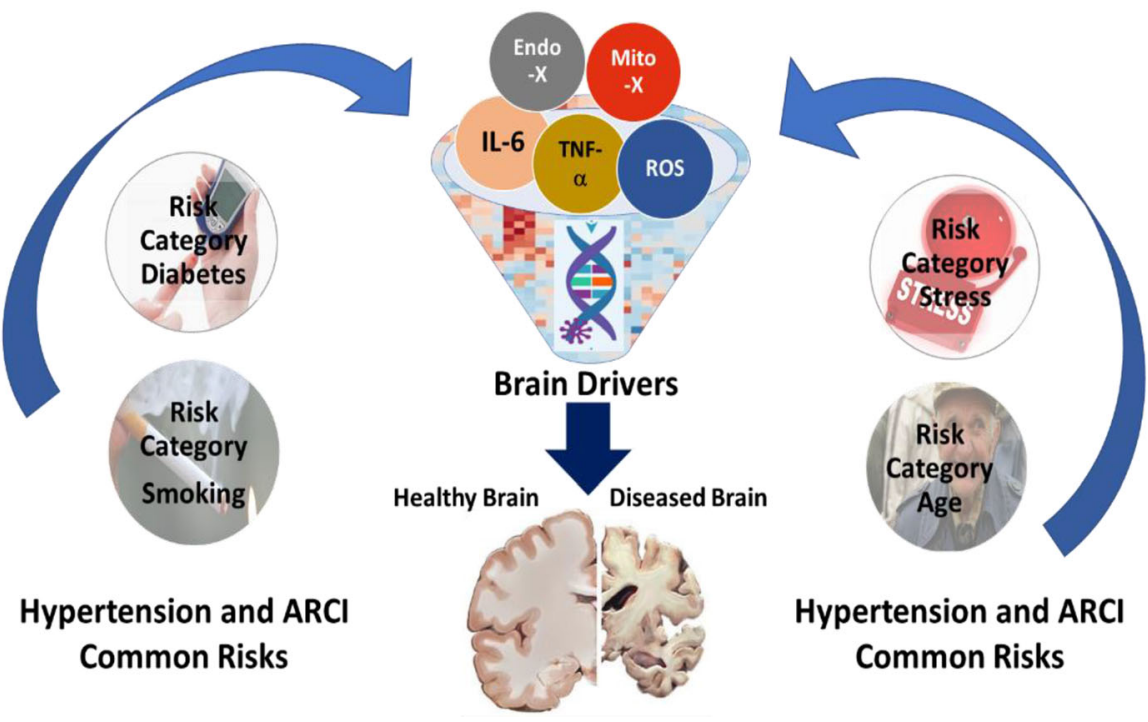

Hypertension and ARCI

Common Risks the specific mechanisms underlying why premenopausal women lose their protection in the presence of $\mathrm{T} 2 \mathrm{D}$, it has been suggested that the T2D-induced endothelial dysfunction overrides any protective effects of ovarian hormones [49].

Adults with T2D also have an increased risk of ARCI and ADRD [53-55]. There have been a number of studies that have shown and increased risk of mild cognitive impairment (MCI) in patients with diabetes with a high risk of conversion from MCI to dementia [56-58]. In a meta-analysis study, it has been shown that T2D is significantly associated with $56 \%$ increase of $\mathrm{AD}$ and $127 \%$ increase of VCID in diabetes patients [59]. Additionally, in a longitudinal study of 918 individuals over the age of 65 who were cognitively normal at baseline, following an 18-month follow-up, it was found that the risk of MCI attributable to diabetes was $8.8 \%$ for the whole entire sample [56]. Similarly, data from the English Longitudinal Study of Ageing (ELSA) investigated the association between $\mathrm{HbA}_{1 \mathrm{c}}$ levels and subsequent cognitive decline in 5189 participants over 50 years of age. This study reported that baseline $\mathrm{HbA}_{1 \mathrm{c}}$ levels were significantly associated with global cognitive, memory, and executive function, and over the 10 years of this study, a $1 \mathrm{mmol} / \mathrm{mol}$ increment in $\mathrm{HbA}_{1 \mathrm{c}}$ was significantly related to an increased rate of decline in global cognitive scores [60].

Many of the same cellular and molecular mechanisms that link diabetes to hypertension have also been implicated in the link between T2D and ARCI and ADRD [61]. Diabetesinduced hyperglycemia results in endothelial cell dysfunction and critically affects the integrity of the blood-brain barrier resulting in increased astrocyte metabolism and ROS production [62]. The increased ROS production stimulates a feedforward cytokine cascade resulting in increased production of proinflammatory cytokines, microglia activation, and ultimately neuronal damage [63]. Hyperglycemia and resultant increases in ROS within the brain also result in neuronal mitochondrial dysfunction and increase in mitochondria oxidative stress $[64,65]$. The neuronal mitochondrial stress results in further increases in inflammatory cascades including increases in TNF $\alpha$, IL-1B, IL-6, and IL-8 [66]. Thus, diabetes-induced increases in brain ROS and inflammation are linked to changes in cognition and ARCI.

In summary, common cellular mechanisms underlying the risk factor of diabetes on hypertension and ARCI include increased systemic and central chronic inflammation including increases in systemic and brain levels of:

\begin{tabular}{ll}
\hline TNF $\alpha$ & Metabolic imbalance \\
IL-6 & Endothelial dysfunction \\
ROS & Mitochondrial stress \\
\hline
\end{tabular}

\section{Smoking: Common Mechanisms with Hypertension and Brain Health}

Smoking of tobacco cigarettes and other tobacco products and their effects on blood pressure are the result of acute and chronic exposure of chemical factors and particulate matter found in tobacco. It has been known for decades that inhalation of tobacco smoke results in direct activation of sympathetic nerve activity in humans and increases catecholamine release from adrenergic nerve terminals [67-69]. In addition, long-term exposure to tobacco smoke alters autonomic nervous system control of blood pressure and attenuates the baroreceptor reflex, thus allowing for unrestrained increase in sympathetic activation by cigarette smoke [69]. Long-term use of tobacco cigarettes is also known to stimulate lung 
afferent $\mathrm{C}$-fibers via inflammation-induced activation of transient receptor potential (TRP) channels which in turn increase cardiac sympathetic activity [70, 71].

Tobacco smoking also is known to result in endothelial dysfunction and decrease flow-mediated dilation and increase inflammation and oxidative stress [72-74]. The endothelial dysfunction is thought to be related to tobacco smoke that induced increased in mitochondrial oxidative stress [75] and inhibition of mitochondrial respiration [76]. In recent study in mice, exposure to cigarette smoke impaired endotheliumdependent vasodilation, increased superoxide production, induced SOD2 hyperacetylation, and reduced expression of endothelial nitric oxide [75]. It is thought that these combined cellular effects of tobacco smoke together contribute to endothelial oxidative stress that impaired blood vessel relaxation and high blood pressure. Smoking is also known to result in increases in chronic inflammation in the vasculature and increases in cell adhesion molecules both of which increase risk of hypertension and cardiovascular disease [77]. Increases in levels of IL-6 and soluble ICAM-1 and MCP-1 have consistently been shown to be significantly associated with tobacco smoking [78-82]. Smokers in the Framingham Heart Study had soluble ICAM-1 levels 25\% higher than nonsmokers [83].

The effects of chronic tobacco smoking on cognitive function have been examined in a number of studies with most showing a clear relationship between current smoking and cognitive function [84-87]. In a study of 5705 participants from the Rotterdam study, the relationship between smoking and cognitive function was examined over a 5.5 year period [88]. These investigators reported that smoking is related to a decline in global cognition among older adults In a review by Durazzo and colleagues [89] of large nonindustry-related cohort studies, the generally accepted conclusion is that longterm smoking results in an approximately $70 \%$ increased risk for developing Alzheimer's disease.

In addition to the cardiovascular/pulmonary effects of smoking, there are studies suggesting that the cellular mechanisms that are involved in chronic smoking effects on heart, blood vessel, and lung damage are also involved in the deleterious effects on brain function and cognition [90]. In studies of younger adults with no overt other diseases, smoking has been shown to decrease performance in measures of executive function, learning and memory, attention, and processing speed [91]. A number of studies have shown that long-term cigarette smoking is significantly associated with decreases in gray and white matter volume and density [92, 93], as measured by magnetic resonance imaging (MRI). In a longitudinal study of 1451 persons over 60 years of age, MRI was used to examine the effects of smoking on hippocampal volume and morphology [94]. In this study, both men and women smokers showed larger rates of hippocampal atrophy as compared with age-matched nonsmokers suggesting that smoking is a major factor in brain aging.
The cellular mechanisms underlying smoking-related morphological brain changes and related cognitive decline include decreases in protective antioxidants [95, 96],increased brain levels oxidative stress [89], and increased inflammatory cytokines and chemokines all of which affect brain health and disease [2]. In a study of older adult smokers with normal cognition, smoking was found to be significantly associated with increases in cerebrospinal fluid levels of F2-isoprostane, a known biomarker of oxidative stress.

Thus, common cellular mechanisms of the risk factor of smoking on both hypertension and ARCI include increased oxidative stress and increased circulating and brain inflammatory cytokines including:

\begin{tabular}{ll}
\hline IL-6 & ICAM-1 \\
TNF $\alpha$ & MCP-1 \\
ROS & Endothelial dysfunction \\
\hline
\end{tabular}

\section{Chronic Stress: Common Mechanisms in Hypertension and Brain Health}

Stress is generally thought to encompass the physiological and emotional responses to various types of either external or internal stimuli [97]. These stimuli can be short-term representing acute stressors or long-term, cumulative stressors representing chronic stress. Chronic stressors can include work-related stress, social isolation, socioeconomic stress as well as physical stress including physical, psychological, or traumatic injury or exposure to biological, chemical, or radiological hazards. The presence of chronic toxic stress from which an individual is unable to adapt to or overcome contributes to the cumulative physiological dysregulation and ultimate decline of multiple physiological systems including cardiovascular function, glucose regulation, and neurological functions $[98,99]$.

Chronic stress is a major risk factor for the development of hypertension [100] and related cardiovascular disease [101, 102]. With regard to blood pressure, both acute and chronic stress are known to activate the sympathetic nervous system to release norepinephrine from sympathetic nerve terminal that cause vasoconstriction and activate the hypothalamicpituitary-adrenal axis (HPA). Activation of the HPA results in the release of corticotrophin-releasing factor (CRF) from neurons in the paraventricular nucleus which, in turn, results in an increase in adrenocorticotropic hormone (ACTH) release from the anterior pituitary as well as release of catecholamines and glucocorticoids from the adrenal gland and release of the mineralocorticoid aldosterone [40]. Continuous activation of the HPA axis results in long-term damage to blood vessel endothelial cells due to sustained sheer stress. Such damage results in increased endothelial cell production of 
inflammatory cytokines such as IL-6, C-reactive protein (CRP), IL-8, PAI-1 [103, 104], and ROS leading to alterations in vascular tone, vascular remodeling, and the development of atherosclerosis [105-107].

The effects of stress and elevated glucocorticoids on brain health were recently reviewed [108•], [109] and have been studied extensively over the last four decades beginning with the seminal paper out of Bruce McEwen's lab showing binding of corticosterone in the hippocampus [110]. Animal studies in rodents have shown that exposure to prolonged, elevated glucocorticoids impairs learning and memory [111], increases neuronal loss in the hippocampus, and decreases neurogenesis in the dentate gyrus [111]. Studies in humans have confirmed that elevated corticosteroids are inversely associated with memory impairments and decreases in hippocampal volume [112]. The mechanism underlying the cognitive effects of prolonged stress and elevated glucocorticoids is thought to be related to their actions on brain cytoplasmic glucocorticoid receptors (GRs) and mineralocorticoid receptors (MRs). Upon ligand activation, these receptors undergo conformational changes resulting in nuclear translocation and activation of glucocorticoid response elements that in turn modify gene expression [113]. The role of GRs and MRs on long-term memory formation and information retrieval involves modulation of hippocampus glutamate neurotransmission, MAPK signaling pathways, CREB phosphorylation, and phosphorylation of synaptic proteins [114]. In some studies, mild acute stress-induced increase in GR activation has been shown to facilitate long-term memory consolidation and is dependent on the temporal relationship between stress events and learning [115]. However, other studies have shown that high levels of psychological stress or high doses of cortisol lead to impairment of learning and memory tasks [116]. This suggests that the relationship between memory performance of complex cognitive tasks to stress is an inverted U-type relationship [117] with the ideal stress/memory relationship found at the peak of the U-type curve decreasing upon continuation of high chronic stress.

In summary, the cellular mechanisms underlying chronic stress effects on both hypertension and cognitive function include increased endothelial cell production of inflammatory cytokines such as:

\begin{tabular}{ll}
\hline IL-6 & PAI-1 \\
CRP & ROS \\
IL-8 & Mitochondrial dysfunction \\
\hline
\end{tabular}

\section{COVID-19: Common Mechanisms with Hypertension and Brain Health}

Recent studies have shown that high blood pressure is the most common comorbidity observed in COVID-19 patients and COVID-19 patients with hypertension have significantly worse disease and death rates vs nonhypertensive patients $[11,118-120]$. In an early study out of China from data on nearly 2000 COVID-19 hospitalized patients, approximately $15 \%$ also exhibited hypertension [121]. In a second study of 1590 COVID-19 patients with a mean age of 49 years, $17 \%$ reported hypertension, and of these patients, $32 \%$ were likely to have severe COVID-19 disease compared with $12.6 \%$ non-hypertensives with severe disease [118]. Importantly, it is also known that age is the most common risk factor for both severe COVID-19 and hypertension. Initial studies out of China have shown that older adults are particularly susceptible to SARS-CoV2 with individuals over 60 years of age accounting for $81 \%$ of the deaths in China [11]. The fatality rate in individuals increases with age with case-fatality rates (CFR) of $14.8 \%$ in patients over $80,8.0 \%$ in patients between 70 and 79 , and $3.6 \%$ in patients between 60 and 69 [11, 121].

The mechanisms underlying the relationship between hypertension and COVID-19 have been suggested to involve the SARS-CoV-2 virus binding to the angiotensinconverting enzyme 2 (ACE2) receptor. This enzyme ACE2 receptor is highly expressed in the kidney, endothelium, lung, brain, and heart and interacts with the spike protein(s) of SARS-COV-2 [122]. Thus, ACE2 is a functional receptor for SARS-COV-2 and serves as an entry point into epithelial and endothelial cells expressing ACE2, such as the mucosa of the respiratory and gastrointestinal tract, as well as vascular endothelial cells. Patients diagnosed with COVID-19 who are admitted into the hospital generally have pneumonia and abnormal chest imaging, and complications include acute respiratory failure, acute respiratory distress syndrome (ARDS), and acute myocardial injury. Recent reports suggest that ARDS appears to be a significant predictor of mortality and a COVID-19-induced "cytokine storm" is thought to be involved in morbidity and mortality [123]. Initial COVID-19-related published studies from Chen et al. reported out on the clinical and immunological characteristics of 41 patients diagnosed with COVID-19 in Wuhan, China [11]. In this study, the authors reported that all 41 patients had pneumonia and a common complication included ARDS (29\%) and cardiac injury (12\%). Both ICU and non-ICU patients showed increases in IL-6, IL-7, IL-8, IL-9, IL-10, TNF $\alpha$, and VEGF as compared with healthy adults. In addition, patients requiring ICU admission had higher concentrations of GCSF, MCP1, MIP1A, and TNF $\alpha$ than did those not requiring $\mathrm{ICU}$ admission.

A number of laboratories across the world are working to develop treatment for COVID-19 and vaccines against SARSCOV-2. Many of these approaches involve developing blockers of the ACE2 virus binding site [122, 124-126]. 
However, while blockade of ACE2 has been shown to block entry of SARS viruses into cells [122], blockade of the ACE2 enzyme will also block the well-known anti-inflammatory tissue protective effects of ACE2 and its essential role in the generation of the protective peptide angiotensin 1-7 (Ang-(1-7). The ACE2 enzyme is a key regulator of lung, heart, vascular, kidney, and brain function and an important component of the well-known renin-angiotensin-system (RAS) [127]. It has become recognized that RAS involves two separate enzymatic pathways that provide a physiological counterbalance of two related peptides acting at distinct receptors. The well-described ACE-AngII-AT1R system is thought to be physiologically opposed and balanced by the ACE2Ang-(1-7)-Mas system [128-130]. Functionally, these two separate enzymatic pathways of RAS are thought to be involved in balancing reactive oxygen species (ROS), nitric oxide (NO) production, and inflammation in peripheral tissues and in the brain $[127,131]$. It has been suggested that a potential adjunct therapy for COVID-19 patients might be the replacement of Ang-(1-7) in COVID-19 patients with a Ang-(1-7) peptide memetic [35] that would be expected to decrease the inflammatory storm and rebalance the ACE2Ang-(1-7)-Mas system and thereby lead to a decrease in mortality in severe COVID-19 patients.

There are similar risk factors between patients with severe COVID-19 and patients at risk for AD, ADRD, and VCID. These include age, inflammation, diabetes, hypertension, hypercholesterolemia, and pulmonary and cardiac disease [16-18, 132]. Early published reports out of China show evidence of neurological manifestations in COVID-19 patients [133]. In the 214 patients studied, neurological symptoms were sorted into three primary categories: (1) central nervous system (CNS) symptoms or diseases (headache, dizziness, impaired consciousness, ataxia, acute cerebrovascular disease, and epilepsy), (2) peripheral nervous system (PNS) symptoms (hypogeusia, hyposmia, hypoplasia, and neuralgia), and (3) skeletal muscular symptoms. Severe disease patients (41.1\%) possessed additional risk factors of hypertension (36.3\%), fever, and cough, and $45.5 \%$ had neurological manifestations. It has been suggested that the CNS complications in COVID-19 may be due to ACE2 expression in the CNS and PNS [134] and the dissemination of SARS-CoV-2 virus either across the cribriform plate or through damaged cerebral vascular endothelial cells, thus leading the viral binding to ACE2 and subsequent budding and neuronal inflammation and damage [135].

In summary, some of the cellular mechanisms that are common to the effects of COVID-19 on both hypertension and cognitive function include increases in:

\begin{tabular}{ll}
\hline TNF $\alpha$ & MCP1 \\
IL-6 & ROS \\
GCSF & Endothelial dysfunction \\
\hline
\end{tabular}

Age: Common Mechanisms with Hypertension and Brain Health

According to the American Heart Association, the risk for hypertension increases in increased age, and the prevalence of high blood pressure is $26 \%$ in persons between 20 and 44 compared with $78 \%$ among those greater than 65 years of age [136]. Vascular aging and related hypertension encompass progressive pathological remodeling of the vascular system resulting in decreased vascular wall elasticity, increased fibrosis, perivascular inflammation, and vascular calcification $[137,138]$. The vascular endothelial cells, which are critical to vascular homeostasis and the regulation of vascular tone, are known to change with increasing age. The role of endothelial cell senescence in age-related vascular function has been recently covered in an excellent review out of the Sowers lab at the University of Missouri [36••]. Similar to other cell types, vascular endothelial cells (ECs) undergo changes with age, and the senescence of the ECs is known to occur when these cells stop dividing and undergo significant phenotypic changes including alterations in cytoskeletal structure, increased cell apoptosis, decreased nitric oxide release, and elevated inflammation [139]. The structural and functional changes that occur with vascular senescence lead to increased arterial stiffness and the loss of the ability of EC to induce vasorelaxation and ultimately an increased risk for hypertension, particularly systolic hypertension and cardiovascular disease [140].

The cellular mechanisms underlying EC senescence and loss of new EC are thought to include a number of mechanism that affect cellular growth and replication, and these include increases in oxidative stress and ROS [141]; increases in vascular inflammation; activation of NF-kappa B; and increases in IL-6, IL-8, TNF-alpha, and activated NLRP3 inflammasome $[142,143]$.

The common cellular mechanisms of hypertension and aging have been reviewed by Buford [144]. The described vascular health triad - chronic low-grade inflammation, chronic increases in oxidative stress, and hypertension - contributes together to create a feed-forward cascade of continual endothelial dysfunction which feeds the increases in inflammatory cytokines and reactive oxygen damage and chronic hypertension [145]. In addition to the age-related EC senescence and associated inflammatory cascades, age-related hypertension has also been linked to changes in insulin-like growth factor (IGF-1) and microvascular rarefaction [146]. Microvascular rarefaction is the reduction in the number of arteriolar and capillary networks that comprise the resistance vessels in the cerebral cortical vascular bed [147]. Microcirculatory rarefaction results in an increase in vascular resistance and decreases oxygen delivery, and in the brain, there is an increase in white matter lesions and loss of cerebral circulation autoregulation [148]. Decreases in microvascular density are significantly 


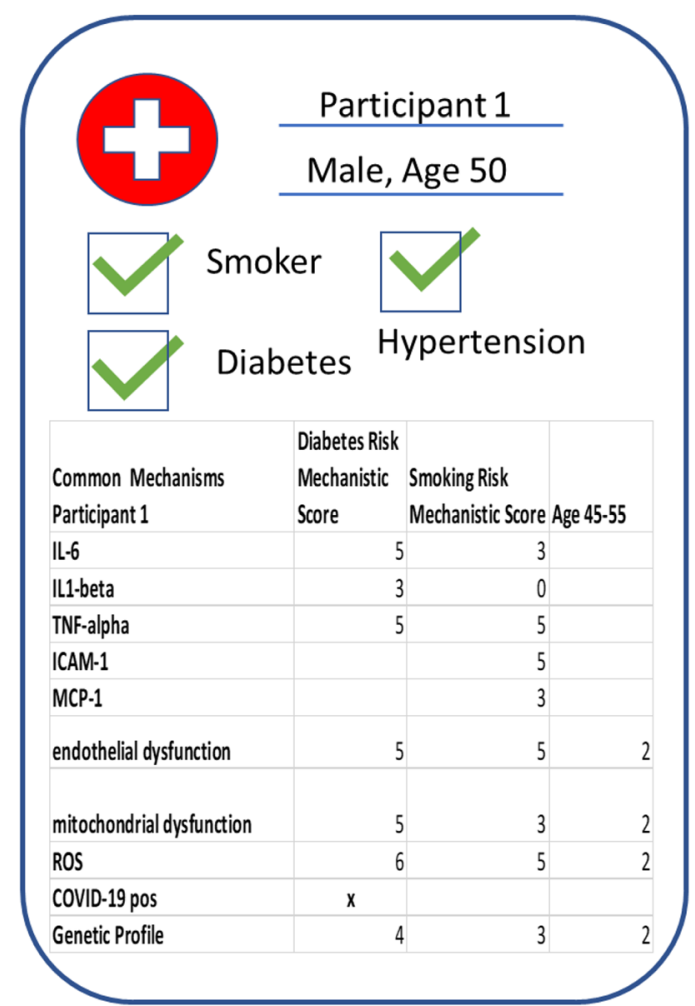

Fig. 2 An illustrative example for how the Precision Aging ${ }^{\circledR}$ approach might be used to derive an individual brain driver signature. Shown is the fictional data from 2 individuals with very different risk "report cards." Both have hypertension that is managed but have different additional risk factors that affect brain health. Due to the convergence of the underlying cellular mechanism that drives the risk categories of diabetes, smoking,

associated with increased peripheral resistance and the onset of hypertension [149, 150]. Factors that are known to modulate vascular and endothelial growth and thus vascular rarefaction included vascular endothelial growth factor (VEGF), growth hormone (GH), and insulin-like growth factor-1 (IGF1). With regard to endothelial cell function and hypertension, IGF-1 has been shown to promote EC cell function and capillary density [151], [36••], and an age-related decline in IGF1 is significantly associated with an increased risk for hypertension [146, 152].

Age has long been known to be the primary risk factor for cognitive impairment. Age is a convenient proxy for a wide array of cellular and molecular mechanisms that underlie ARCI. These include mitochondrial dysfunction [153], oxidative stress and increased ROS production, decreased brain lysosomal function [154], decreased levels of synaptic proteins such as neuronal pentraxin 2 [155], and increased brain inflammation and microglia activation as well as changes in cerebral perfusion and brain oxygenation [156].

Changes in endothelial cell function and their role in brain blood flow autoregulation have been suggested to be involved in age-related changes in cognitive function [1]. In studies of cerebral blood flow using perfusion MRI and internal carotid

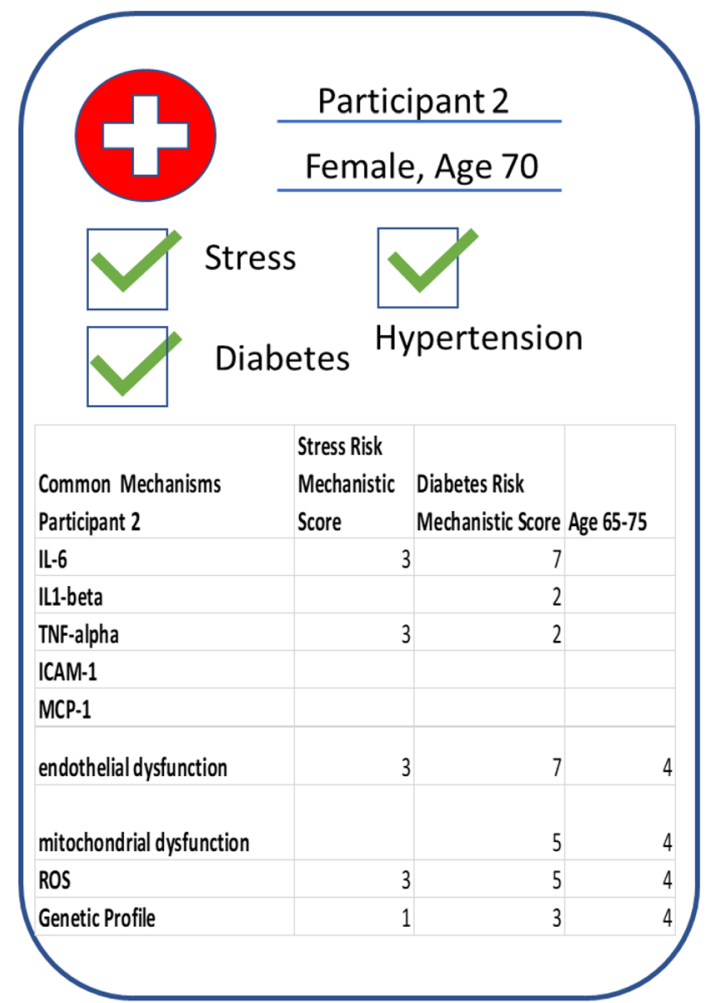

stress, sex, and age, the combined scores for levels of IL-6, IL-1beta, TNA-alpha, ICAM-1, MCDP-1, ROS, endothelial dysfunction, and mitochondrial dysfunction can be measured and assigned a unique value for each individual in accordance with age, sex, and the extent of the concomitant disease (e.g., diabetes) and levels of risk exposure (e.g., years smoking or stress level)

ultrasound in individuals over 75 years of age, cerebral blood flow was found to be reduced in healthy older adults compared with healthy young adults (approximately 28 years of age), and decreases were significantly associated with increasing levels of cognitive dysfunction [157•]. These age-related changes in cerebral blood flow were also related to decreases in circulation of NO bioavailability.

The role of systemic and brain inflammation in aging and its effect on cognitive function have been the focus on many investigations and recent reviews [158], [159••]. In older subjects with chronic inflammatory diseases such as heart failure, increases in circulating levels of proinflammatory cytokines have been shown to result in decreases in cognitive function [160-162]. Increases in circulating levels of TNF-alpha, IL-6, and CRP have all been significantly associated with age-related memory impairment and executive function [132, 163-166].

In summary, some of the cellular mechanisms that are common to the effects of aging on both hypertension and cognitive function include increases in:

\begin{tabular}{ll}
\hline IL-6 & Endothelial senescence \\
IL-8 & Activated NLRP3 inflammasome \\
TNF $\alpha$ & Mitochondrial dysfunction \\
\hline
\end{tabular}




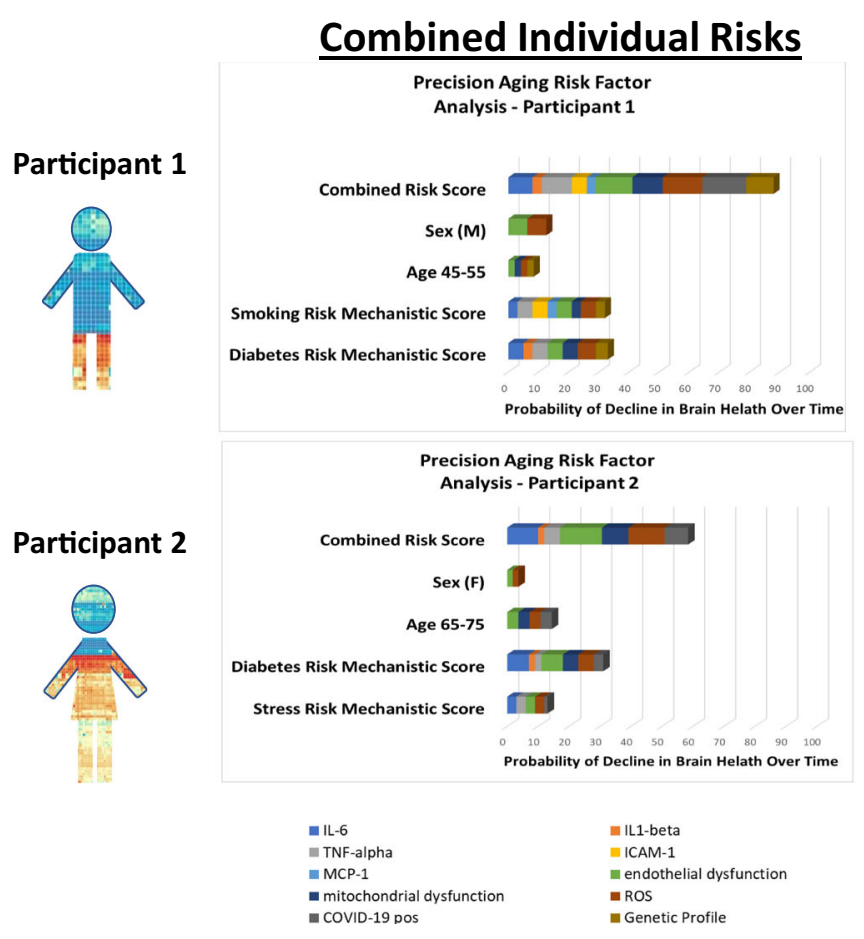

Fig. 3 Illustration of how the data from the risk factor report cards are combined to create an individualized brain driver signature. Precision Aging ${ }^{\circledR}$ then combines this individual profile risk score with large, big

\section{Perspectives}

The goal of matching one's cognitive health span to their life span requires detailed integration of data regarding an individual's specific risk factors and the underlying cellular and genetic mechanisms driving brain and cognitive health. It is clear that both hypertension and ARCI are influenced by similar risk factors and share mechanistic underpinnings. These mechanisms converge and are amplified to predict an individual's cognitive aging trajectory.

In order to design and ultimately prescribe individual interventions to optimize cognitive health span, we are informed by examples given by Precision Medicine and individualized cancer therapeutics. Precision Medicine, with regard to cancer, uses the genetic information in an individual's tumor to define the treatment path. With Precision Aging ${ }^{\circledR}$, we suggest that one can use not only an individual's specific genetic risk profile for factors that contribute to cognitive aging but also risk profiles and combined cellular mechanistic scores related to factors such as smoking, diabetes, stress, age, and sex to establish an individualized brain health trajectory.

Figure 2 is an illustrative example of risk factor score report cards from 2 different participants. Mechanisms measured include IL-6, IL1-beta, TNF-alpha, ICAM-1, MCP-1, ROS, endothelial dysfunction, and mitochondrial dysfunction.

\section{Precision Aging ${ }^{\circledast}$ Integrates Individual Profile + Big Data to Predict Individual Cognitive Health Trajectory}

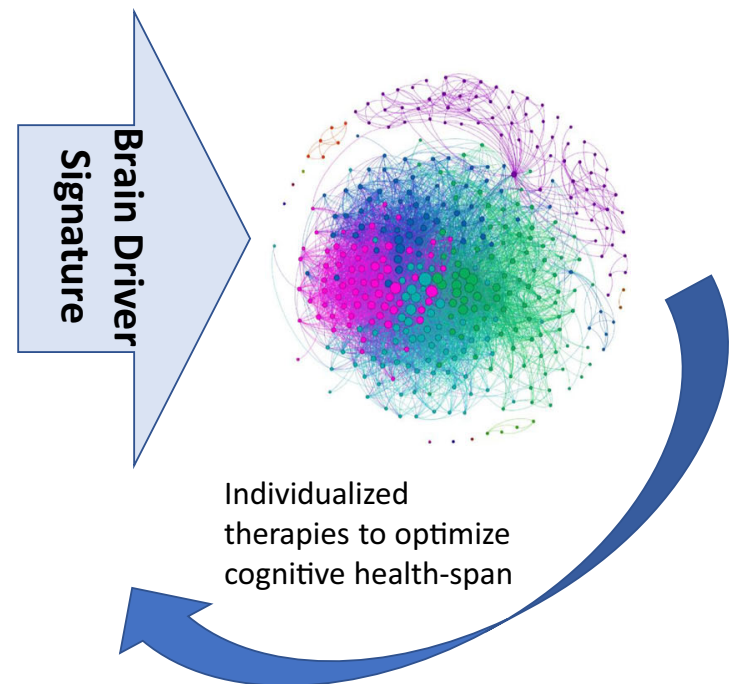

data sets to predict an individual cognitive health trajectory. Specific individualized interventions could then be created to optimize an individual's cognitive health span

Participant 1 is male and under 60 years of age with managed hypertension. But he is also a chronic smoker and has unmanaged diabetes and tested positive for COVID-19. His common mechanism scores and genetic profile scores are combined to create a total risk score. This can be compared with participant 2 who is female and 70 years of age who also has managed hypertension. Her common mechanism scores include scores for stress and managed diabetes that are combined to create a unique total risk score. Combined Risk Score is illustrated in Fig. 3.

As illustrated in Fig. 3, we can conceivably combine an individual's scores for each of the key cellular mechanism to create a "Combined Risk Score" that defines an individual's brain driver signature. Precision Aging $\AA$ then compares this profile risk score with a large, normative database to predict an individual's cognitive health trajectory. Specific individualized interventions could then be created to optimize an individual's cognitive health span.

Authors' Contributions Study concept and design: Dr. Hay. Literature review, analysis, and interpretation of data: all authors. Drafting of the manuscript: all authors. Critical revision of the manuscript for important intellectual content: all authors.

\section{Compliance with Ethical Standards}

Conflict of Interest The authors declare that they have no conflict of interest. 
Human and Animal Rights and Informed Consent This article does not contain any studies with human or animal subjects performed by any of the authors.

\section{References}

Papers of particular interest, published recently, have been highlighted as:

- Of importance

•- Of major importance

1. Sweeney MD, Montagne A, Sagare AP, Nation DA, Schneider LS, Chui HC, et al. Vascular dysfunction-the disregarded partner of Alzheimer's disease. Alzheimers Dement. 2019;15(1):158-67. https://doi.org/10.1016/j.jalz.2018.07.222 This review outlines the mulitfactorial contributions to Alzheimer's disease and the essential role of vascualar disease and related biomarkers.

2.• Ryan L, Hay M, Huentelman MJ, Duarte A, Rundek T, Levin B, et al. Precision aging: applying precision medicine to the field of cognitive aging. Front Aging Neurosci. 2019;11:128. https://doi. org/10.3389/fnagi.2019.00128 In depth review that identifies multiple physiolgical and pathophysiolical drivers of brain heatlh and disease.

3. Clarke LE, Liddelow SA, Chakraborty C, Münch AE, Heiman M, Barres BA. Normal aging induces A1-like astrocyte reactivity. Proc Natl Acad Sci U S A. 2018;115(8):E1896-E905. https:/ doi.org/10.1073/pnas.1800165115.

4. Janota C, Lemere CA, Brito MA. Dissecting the contribution of vascular alterations and aging to Alzheimer's disease. Mol Neurobiol. 2016;53(6):3793-811. https://doi.org/10.1007/ s12035-015-9319-7.

5. Love S, Miners JS. Cerebral hypoperfusion and the energy deficit in Alzheimer's disease. Brain Pathol. 2016;26(5):607-17. https:// doi.org/10.1111/bpa.12401.

6. Emdin CA, Anderson SG, Woodward M, Rahimi K. Usual blood pressure and risk of new-onset diabetes: evidence from 4.1 million adults and a meta-analysis of prospective studies. J Am Coll Cardiol. 2015;66(14):1552-62. https://doi.org/10.1016/j.jacc. 2015.07.059.

7. Berchtold NC, Coleman PD, Cribbs DH, Rogers J, Gillen DL, Cotman CW. Synaptic genes are extensively downregulated across multiple brain regions in normal human aging and Alzheimer's disease. Neurobiol Aging. 2013;34(6):1653-61. https://doi.org/10.1016/j.neurobiolaging.2012.11.024.

8. Promotion NCfCDPaH, DfHDaSP. High Blood Pressure Facts https://www.cdc.gov/bloodpressure/index.htm.

9. Association TAH. High blood pressure. https://www.heart.org/en/ health-topics/high-blood-pressure.

10. Shimabukuro-Vornhagen A, Gödel P, Subklewe M, Stemmler HJ, Schlößer HA, Schlaak M, et al. Cytokine release syndrome. J Immunother Cancer. 2018;6(1):56. https://doi.org/10.1186/ s40425-018-0343-9.

11. Huang C, Wang Y, Li X, Ren L, Zhao J, Hu Y et al. Clinical features of patients infected with 2019 novel coronavirus in Wuhan, China Lancet 2020;395(10223):497-506. doi:https://doi. org/10.1016/S0140-6736(20)30183-5.

12. Wong CK, Lam CW, Wu AK, Ip WK, Lee NL, Chan IH, et al. Plasma inflammatory cytokines and chemokines in severe acute respiratory syndrome. Clin Exp Immunol. 2004;136(1):95-103. https://doi.org/10.1111/j.1365-2249.2004.02415.x.
13. Mills KT, Stefanescu A, He J. The global epidemiology of hypertension. Nat Rev Nephrol. 2020;16(4):223-37. https://doi.org/10. 1038/s41581-019-0244-2.

14. Association As. https://www.alz.org/alzheimers-dementia/whatis-dementia/types-of-dementia/vascular-dementia.

15. Wagster MV, King JW, Resnick SM, Rapp PR. The 87\%. J Gerontol A Biol Sci Med Sci. 2012;67(7):739-40. https://doi. org/10.1093/gerona/gls140.

16. Kapasi A, Schneider JA. Vascular contributions to cognitive impairment, clinical Alzheimer's disease, and dementia in older persons. Biochim Biophys Acta. 2016;1862(5):878-86. https://doi. org/10.1016/j.bbadis.2015.12.023.

17. Toledo JB, Toledo E, Weiner MW, Jack CR, Jagust W, Lee VM, et al. Cardiovascular risk factors, cortisol, and amyloid- $\beta$ deposition in Alzheimer's disease neuroimaging initiative. Alzheimers Dement. 2012;8(6):483-9. https://doi.org/10.1016/j.jalz.2011.08. 008.

18. Yarchoan M, Xie SX, Kling MA, Toledo JB, Wolk DA, Lee EB, et al. Cerebrovascular atherosclerosis correlates with Alzheimer pathology in neurodegenerative dementias. Brain. 2012;135(Pt 12):3749-56. https://doi.org/10.1093/brain/aws271.

19. van Oijen M, de Jong FJ, Witteman JC, Hofman A, Koudstaal PJ, Breteler MM. Atherosclerosis and risk for dementia. Ann Neurol. 2007;61(5):403-10. https://doi.org/10.1002/ana.21073.

20. Gorelick PB, Furie KL, Iadecola C, Smith EE, Waddy SP, LloydJones DM, et al. Defining optimal brain health in adults: a presidential advisory from the American Heart Association/American Stroke Association. Stroke. 2017;48(10):e284-303. https://doi. org/10.1161/STR.0000000000000148.

21. Santos CY, Snyder PJ, Wu WC, Zhang M, Echeverria A, Alber J. Pathophysiologic relationship between Alzheimer's disease, cerebrovascular disease, and cardiovascular risk: a review and synthesis. Alzheimers Dement (Amst). 2017;7:69-87. https://doi.org/10. 1016/j.dadm.2017.01.005.

22. Canobbio I, Abubaker AA, Visconte C, Torti M, Pula G. Role of amyloid peptides in vascular dysfunction and platelet dysregulation in Alzheimer's disease. Front Cell Neurosci. 2015;9:65. https://doi.org/10.3389/fncel.2015.00065.

23. Association As. World Alzheimer Report 2010: The global economic impact of dementia. https://www.alz.org/news/2010/newreport-reveals-global-cost-of-alzheimer_s-and.

24. Egan BM, Zhao Y, Axon RN. US trends in prevalence, awareness, treatment, and control of hypertension, 1988-2008. JAMA. 2010;303(20):2043-50. https://doi.org/10.1001/jama.2010.650.

25. Wang G, Zhou X, Zhuo X, Zhang P. Annual total medical expenditures associated with hypertension by diabetes status in U.S. adults. Am J Prev Med. 2017;53(6S2):S182-S9. https://doi.org/ 10.1016/j.amepre.2017.07.018.

26. Levin G, Kestenbaum B, Ida Chen YD, Jacobs DR, Psaty BM, Rotter JI, et al. Glucose, insulin, and incident hypertension in the multi-ethnic study of atherosclerosis. Am J Epidemiol. 2010;172(10):1144-54. https://doi.org/10.1093/aje/kwq266.

27. Gress TW, Nieto FJ, Shahar E, Wofford MR, Brancati FL. Hypertension and antihypertensive therapy as risk factors for type 2 diabetes mellitus. Atherosclerosis risk in communities study. $\mathrm{N}$ Engl J Med. 2000;342(13):905-12. https://doi.org/10.1056/ NEJM200003303421301.

28. Aksnes TA, Kjeldsen SE, Rostrup M, Störset O, Hua TA, Julius S. Predictors of new-onset diabetes mellitus in hypertensive patients: the VALUE trial. J Hum Hypertens. 2008;22(8):520-7. https:// doi.org/10.1038/jhh.2008.41.

29. Cheung BM, Li C. Diabetes and hypertension: is there a common metabolic pathway? Curr Atheroscler Rep. 2012;14(2):160-6. https://doi.org/10.1007/s11883-012-0227-2.

30. da Silva AA, do Carmo JM, Li X, Wang Z, Mouton AJ, Hall JE. Role of hyperinsulinemia and insulin resistance in hypertension: 
metabolic syndrome revisited. Can J Cardiol. 2020;36(5):671-82. https://doi.org/10.1016/j.cjca.2020.02.066.

31. Giacco F, Brownlee M. Oxidative stress and diabetic complications. Circ Res. 2010;107(9):1058-70. https://doi.org/10.1161/ CIRCRESAHA.110.223545.

32. Brownlee M. Biochemistry and molecular cell biology of diabetic complications. Nature. 2001;414(6865):813-20. https://doi.org/ 10.1038/414813a.

33. Srivastava SK, Ramana KV, Bhatnagar A. Role of aldose reductase and oxidative damage in diabetes and the consequent potential for therapeutic options. Endocr Rev. 2005;26(3):380-92. https://doi.org/10.1210/er.2004-0028.

34. Xue B, Beltz TG, Yu Y, Guo F, Gomez-Sanchez CE, Hay M, et al. Central interactions of aldosterone and angiotensin II in aldosterone- and angiotensin II-induced hypertension. Am J Physiol Heart Circ Physiol. 2011;300(2):H555-64.

35. Hay M, Polt R, Heien ML, Vanderah TW, Largent-Milnes TM, Rodgers K, et al. A novel angiotensin-(1-7) glycosylated mas receptor agonist for treating vascular cognitive impairment and inflammation-related memory dysfunction. J Pharmacol Exp Ther. 2019;369(1):9-25. https://doi.org/10.1124/jpet.118.254854.

36.• Jia G, Aroor AR, Jia C, Sowers JR. Endothelial cell senescence in aging-related vascular dysfunction. Biochim Biophys Acta Mol basis Dis. 2019;1865(7):1802-9. https://doi.org/10.1016/j. bbadis.2018.08.008 This excellent review outlines the multiple mechanisms that undery age-related changes in vascular function.

37. Touyz RM, Yao G, Viel E, Amiri F, Schiffrin EL. Angiotensin II and endothelin-1 regulate MAP kinases through different redoxdependent mechanisms in human vascular smooth muscle cells. J Hypertens. 2004;22(6):1141-9.

38. Touyz RM, Rios FJ, Alves-Lopes R, Neves KB, Camargo LL, Montezano AC. Oxidative stress: a unifying paradigm in hypertension. Can J Cardiol. 2020;36(5):659-70. https://doi.org/10. 1016/j.cjca.2020.02.081.

39. Dubey RK, Oparil S, Imthurn B, Jackson EK. Sex hormones and hypertension. Cardiovasc Res. 2002;53(3):688-708.

40. Hay M. Sex, the brain and hypertension: brain oestrogen receptors and high blood pressure risk factors. Clin Sci (Lond). 2016;130(1):9-18. https://doi.org/10.1042/CS20150654.

41. Sandberg K, Ji H. Sex differences in primary hypertension. Biol Sex Differ. 2012;3(1):7. https://doi.org/10.1186/2042-6410-3-7.

42. Reckelhoff JF. Sex differences in regulation of blood pressure. Adv Exp Med Biol. 2018;1065:139-51. https://doi.org/10.1007/ 978-3-319-77932-4_9.

43. Reckelhoff JF, Maric C. Sex and gender differences in cardiovascular-renal physiology and pathophysiology. Steroids. 2010;75(11):745-6. https://doi.org/10.1016/j.steroids.2010.05. 020.

44. Cutler JA, Sorlie PD, Wolz M, Thom T, Fields LE, Roccella EJ. Trends in hypertension prevalence, awareness, treatment, and control rates in United States adults between 1988-1994 and 19992004. Hypertension. 2008;52(5):818-27. https://doi.org/10.1161/ HYPERTENSIONAHA.108.113357.

45. Yanes LL, Romero DG, Iliescu R, Reckelhoff JF. A single pill to treat postmenopausal hypertension? Not yet. Curr Top Med Chem. 2011;11(13):1736-41.

46. Crandall CJ, Barrett-Connor E. Endogenous sex steroid levels and cardiovascular disease in relation to the menopause: a systematic review. Endocrinol Metab Clin N Am. 2013;42(2):227-53. https://doi.org/10.1016/j.ecl.2013.02.003.

47. Barrett-Connor E. The Rancho Bernardo study: 40 years studying why women have less heart disease than men and how diabetes modifies women's usual cardiac protection. Glob Heart. 2013;8(2). doi:https://doi.org/10.1016/j.gheart.2012.12.002.
48. Lee SJ, Lee DW, Kim KS, Lee IK. Effect of estrogen on endothelial dysfunction in postmenopausal women with diabetes. Diabetes Res Clin Pract. 2001;54(Suppl 2):S81-92. https://doi. org/10.1016/s0168-8227(01)00339-4.

49. Maric-Bilkan C. Sex differences in micro- and macro-vascular complications of diabetes mellitus. Clin Sci (Lond). 2017;131(9):833-46. https://doi.org/10.1042/CS20160998.

50. Hay M, Xue B, Johnson AK. Yes! Sex matters: sex, the brain and blood pressure. Curr Hypertens Rep. 2014;16(8):458. https://doi. org/10.1007/s11906-014-0458-4.

51. Xue B, Beltz TG, Johnson RF, Guo F, Hay M, Johnson AK. PVN adenovirus-siRNA injections silencing either NOX2 or NOX4 attenuate aldosterone $/ \mathrm{NaCl}$-induced hypertension in mice. Am J Physiol Heart Circ Physiol. 2012;302(3):H733-41. https://doi. org/10.1152/ajpheart.00873.2011.

52. Regensteiner JG, Golden S, Huebschmann AG, Barrett-Connor E, Chang AY, Chyun D, et al. Sex differences in the cardiovascular consequences of diabetes mellitus: a scientific statement from the American Heart Association. Circulation. 2015;132(25):2424- 47. https://doi.org/10.1161/CIR.0000000000000343.

53. Ryan CM, van Duinkerken E, Rosano C. Neurocognitive consequences of diabetes. Am Psychol. 2016;71(7):563-76. https://doi. org/10.1037/a0040455.

54. Biessels GJ, Strachan MW, Visseren FL, Kappelle LJ, Whitmer RA. Dementia and cognitive decline in type 2 diabetes and prediabetic stages: towards targeted interventions. Lancet Diabetes Endocrinol. 2014;2(3):246-55. https://doi.org/10.1016/S22138587(13)70088-3.

55. Zilliox LA, Chadrasekaran K, Kwan JY, Russell JW. Diabetes and cognitive impairment. Curr Diab Rep. 2016;16(9):87. https://doi. org/10.1007/s11892-016-0775-X.

56. Luchsinger JA, Reitz C, Patel B, Tang MX, Manly JJ, Mayeux R. Relation of diabetes to mild cognitive impairment. Arch Neurol. 2007;64(4):570-5. https://doi.org/10.1001/archneur.64.4.570.

57. Roberts RO, Knopman DS, Przybelski SA, Mielke MM, Kantarci K, Preboske GM, et al. Association of type 2 diabetes with brain atrophy and cognitive impairment. Neurology. 2014;82(13): 1132-41. https://doi.org/10.1212/WNL.0000000000000269.

58. Li J, Cesari M, Liu F, Dong B, Vellas B. Effects of diabetes mellitus on cognitive decline in patients with Alzheimer disease: a systematic review. Can J Diabetes. 2017;41(1):114-9. https:// doi.org/10.1016/j.jcjd.2016.07.003.

59. Gudala K, Bansal D, Schifano F, Bhansali A. Diabetes mellitus and risk of dementia: a meta-analysis of prospective observational studies. J Diabetes Investig. 2013;4(6):640-50. https://doi.org/10. 1111/jdi.12087.

60. Zheng F, Yan L, Yang Z, Zhong B, Xie W. HbA Diabetologia 2018;61(4):839-48. doi:https://doi.org/10.1007/s00125-0174541-7.

61. Jash K, Gondaliya P, Kirave P, Kulkarni B, Sunkaria A, Kalia K. Cognitive dysfunction: a growing link between diabetes and Alzheimer's disease. Drug Dev Res. 2020;81(2):144-64. https:// doi.org/10.1002/ddr.21579.

62. Li W, Roy Choudhury G, Winters A, Prah J, Lin W, Liu R, et al. Hyperglycemia alters astrocyte metabolism and inhibits astrocyte proliferation. Aging Dis. 2018;9(4):674-84. https://doi.org/10. 14336/AD.2017.1208

63. Salim S. Oxidative stress and the central nervous system. J Pharmacol Exp Ther. 2017;360(1):201-5. https://doi.org/10. 1124/jpet.116.237503.

64. Cenini G, Lloret A, Cascella R. Oxidative stress in neurodegenerative diseases: from a mitochondrial point of view. Oxidative Med Cell Longev. 2019;2019:2105607-18. https://doi.org/10.1155/ 2019/2105607.

65. Golpich M, Amini E, Mohamed Z, Azman Ali R, Mohamed Ibrahim N, Ahmadiani A. Mitochondrial dysfunction and 
biogenesis in neurodegenerative diseases: pathogenesis and treatment. CNS Neurosci Ther. 2017;23(1):5-22. https://doi.org/10. $1111 /$ cns. 12655 .

66. Liyanagamage DSNK, Martinus RD. Role of mitochondrial stress protein HSP60 in diabetes-induced neuroinflammation. Mediat Inflamm. 2020;2020:8073516. https://doi.org/10.1155/2020/ 8073516.

67. Narkiewicz K, van de Borne PJ, Hausberg M, Cooley RL, Winniford MD, Davison DE, et al. Cigarette smoking increases sympathetic outflow in humans. Circulation. 1998;98(6):528-34. https://doi.org/10.1161/01.cir.98.6.528.

68. Esler M. Clinical application of noradrenaline spillover methodology: delineation of regional human sympathetic nervous responses. Pharmacol Toxicol. 1993;73(5):243-53. https://doi.org/ 10.1111/j.1600-0773.1993.tb00579.x.

69. Middlekauff HR, Park J, Moheimani RS. Adverse effects of cigarette and noncigarette smoke exposure on the autonomic nervous system: mechanisms and implications for cardiovascular risk. J Am Coll Cardiol. 2014;64(16):1740-50. https://doi.org/10.1016/ j.jacc.2014.06.1201.

70. Ghelfi E, Wellenius GA, Lawrence J, Millet E, Gonzalez-Flecha B. Cardiac oxidative stress and dysfunction by fine concentrated ambient particles (CAPs) are mediated by angiotensin-II. Inhal Toxicol. 2010;22(11):963-72. https://doi.org/10.3109/08958378. 2010.503322

71. Andrè E, Campi B, Materazzi S, Trevisani M, Amadesi S, Massi $\mathrm{D}$, et al. Cigarette smoke-induced neurogenic inflammation is mediated by alpha,beta-unsaturated aldehydes and the TRPA1 receptor in rodents. J Clin Invest. 2008;118(7):2574-82. https://doi.org/ 10.1172/JCI34886.

72. Carnevale R, Sciarretta S, Violi F, Nocella C, Loffredo L, Perri L, et al. Acute impact of tobacco vs electronic cigarette smoking on oxidative stress and vascular function. Chest. 2016;150(3):60612. https://doi.org/10.1016/j.chest.2016.04.012.

73. Celermajer DS, Sorensen KE, Georgakopoulos D, Bull C, Thomas O, Robinson J, et al. Cigarette smoking is associated with dose-related and potentially reversible impairment of endothelium-dependent dilation in healthy young adults. Circulation. 1993;88(5 Pt 1):2149-55. https://doi.org/10.1161/ 01.cir.88.5.2149.

74. Zeiher AM, Schächinger V, Minners J. Long-term cigarette smoking impairs endothelium-dependent coronary arterial vasodilator function. Circulation. 1995;92(5):1094-100. https://doi. org/10.1161/01.cir.92.5.1094.

75. Dikalov S, Itani H, Richmond B, Vergeade A, Rahman SMJ, Boutaud $\mathrm{O}$, et al. Tobacco smoking induces cardiovascular mitochondrial oxidative stress, promotes endothelial dysfunction, and enhances hypertension. Am J Physiol Heart Circ Physiol. 2019;316(3):H639-H46. https://doi.org/10.1152/ajpheart.00595. 2018.

76. van der Toorn M, Slebos DJ, de Bruin HG, Leuvenink HG, Bakker SJ, Gans RO, et al. Cigarette smoke-induced blockade of the mitochondrial respiratory chain switches lung epithelial cell apoptosis into necrosis. Am J Phys Lung Cell Mol Phys. 2007;292(5):L1211-8. https://doi.org/10.1152/ajplung.00291. 2006.

77. Ambrose JA, Barua RS. The pathophysiology of cigarette smoking and cardiovascular disease: an update. J Am Coll Cardiol. 2004;43(10):1731-7. https://doi.org/10.1016/j.jacc. 2003.12.047.

78. Al Rifai M, DeFilippis AP, McEvoy JW, Hall ME, Acien AN, Jones MR, et al. The relationship between smoking intensity and subclinical cardiovascular injury: the multi-ethnic study of atherosclerosis (MESA). Atherosclerosis. 2017;258:119-30. https://doi. org/10.1016/j.atherosclerosis.2017.01.021.
79. Bermudez EA, Rifai N, Buring J, Manson JE, Ridker PM. Interrelationships among circulating interleukin-6, C-reactive protein, and traditional cardiovascular risk factors in women. Arterioscler Thromb Vasc Biol. 2002;22(10):1668-73. https:// doi.org/10.1161/01.atv.0000029781.31325.66.

80. Frost-Pineda K, Liang Q, Liu J, Rimmer L, Jin Y, Feng S, et al. Biomarkers of potential harm among adult smokers and nonsmokers in the total exposure study. Nicotine Tob Res. 2011;13(3):182-93. https://doi.org/10.1093/ntr/ntq235.

81. Levitzky YS, Guo CY, Rong J, Larson MG, Walter RE, Keaney $\mathrm{JF}$, et al. Relation of smoking status to a panel of inflammatory markers: the Framingham offspring. Atherosclerosis. 2008;201(1):217-24. https://doi.org/10.1016/j.atherosclerosis. 2007.12.058

82. McEvoy JW, Nasir K, DeFilippis AP, Lima JA, Bluemke DA, Hundley WG, et al. Relationship of cigarette smoking with inflammation and subclinical vascular disease: the multi-ethnic study of atherosclerosis. Arterioscler Thromb Vasc Biol. 2015;35(4):1002-10. https://doi.org/10.1161/ATVBAHA.114. 304960 .

83. Keaney JF, Massaro JM, Larson MG, Vasan RS, Wilson PW, Lipinska I, et al. Heritability and correlates of intercellular adhesion molecule-1 in the Framingham Offspring Study. J Am Coll Cardiol. 2004;44(1):168-73. https://doi.org/10.1016/j.jacc.2004. 03.048.

84. Peters R, Poulter R, Warner J, Beckett N, Burch L, Bulpitt C. Smoking, dementia and cognitive decline in the elderly, a systematic review. BMC Geriatr. 2008;8:36. https://doi.org/10.1186/ 1471-2318-8-36.

85. Reitz C, Luchsinger J, Tang MX, Mayeux R. Effect of smoking and time on cognitive function in the elderly without dementia. Neurology. 2005;65(6):870-5. https://doi.org/10.1212/01.wnl. 0000176057.22827.b7.

86. Ott A, Andersen K, Dewey ME, Letenneur L, Brayne C, Copeland $\mathrm{JR}$, et al. Effect of smoking on global cognitive function in nondemented elderly. Neurology. 2004;62(6):920-4. https://doi. org/10.1212/01.wnl.0000115110.35610.80.

87. Cataldo JK, Prochaska JJ, Glantz SA. Cigarette smoking is a risk factor for Alzheimer's disease: an analysis controlling for tobacco industry affiliation. J Alzheimers Dis. 2010;19(2):465-80. https:// doi.org/10.3233/JAD-2010-1240.

88. Wingbermühle R, Wen KX, Wolters FJ, Ikram MA, Bos D. Smoking, APOE genotype, and cognitive decline: the Rotterdam study. J Alzheimers Dis. 2017;57(4):1191-5. https://doi.org/10. 3233/JAD-170063.

89. Durazzo TC, Mattsson N, Weiner MW. Initiative AsDN. Smoking and increased Alzheimer's disease risk: a review of potential mechanisms. Alzheimers Dement. 2014;10(3 Suppl):S122-45. https://doi.org/10.1016/j.jalz.2014.04.009.

90. Durazzo TC, Korecka M, Trojanowski JQ, Weiner MW, O'Hara $\mathrm{R}$, Ashford JW, et al. Active cigarette smoking in cognitivelynormal elders and probable Alzheimer's disease is associated with elevated cerebrospinal fluid oxidative stress biomarkers. J Alzheimers Dis. 2016;54(1):99-107. https://doi.org/10.3233/ JAD-160413.

91. Durazzo TC, Meyerhoff DJ, Yoder KK. Cigarette smoking is associated with cortical thinning in anterior frontal regions, insula and regions showing atrophy in early Alzheimer's disease. Drug Alcohol Depend. 2018;192:277-84. https://doi.org/10.1016/j. drugalcdep.2018.08.009.

92. Brody AL, Mandelkern MA, Jarvik ME, Lee GS, Smith EC, Huang JC, et al. Differences between smokers and nonsmokers in regional gray matter volumes and densities. Biol Psychiatry. 2004;55(1):77-84. https://doi.org/10.1016/s0006-3223(03) 00610-3. 
93. Gallinat J, Meisenzahl E, Jacobsen LK, Kalus P, Bierbrauer J, Kienast T, et al. Smoking and structural brain deficits: a volumetric MR investigation. Eur J Neurosci. 2006;24(6):1744-50. https://doi.org/10.1111/j.1460-9568.2006.05050.x.

94. Duriez Q, Crivello F, Mazoyer B. Sex-related and tissue-specific effects of tobacco smoking on brain atrophy: assessment in a large longitudinal cohort of healthy elderly. Front Aging Neurosci. 2014;6:299. https://doi.org/10.3389/fnagi.2014.00299.

95. Moriarty SE, Shah JH, Lynn M, Jiang S, Openo K, Jones DP, et al. Oxidation of glutathione and cysteine in human plasma associated with smoking. Free Radic Biol Med. 2003;35(12):1582-8. https:// doi.org/10.1016/j.freeradbiomed.2003.09.006.

96. Bloomer RJ. Decreased blood antioxidant capacity and increased lipid peroxidation in young cigarette smokers compared to nonsmokers: impact of dietary intake. Nutr J. 2007;6:39. https://doi. org/10.1186/1475-2891-6-39.

97. Shonkoff JP, Boyce WT, McEwen BS. Neuroscience, molecular biology, and the childhood roots of health disparities: building a new framework for health promotion and disease prevention. JAMA. 2009;301(21):2252-9. https://doi.org/10.1001/jama. 2009.754 .

98. Juster RP, McEwen BS, Lupien SJ. Allostatic load biomarkers of chronic stress and impact on health and cognition. Neurosci Biobehav Rev. 2010;35(1):2-16. https://doi.org/10.1016/j. neubiorev.2009.10.002.

99. McEwen BS. Allostasis and the epigenetics of brain and body health over the life course: the brain on stress. JAMA Psychiatry. 2017;74(6):551-2. https://doi.org/10.1001/ jamapsychiatry.2017.0270.

100. Munakata M. Clinical significance of stress-related increase in blood pressure: current evidence in office and out-of-office settings. Hypertens Res. 2018;41(8):553-69. https://doi.org/10. 1038/s41440-018-0053-1.

101. Hering D, Lachowska K, Schlaich M. Role of the sympathetic nervous system in stress-mediated cardiovascular disease. Curr Hypertens Rep. 2015;17(10):594. https://doi.org/10.1007/ s11906-015-0594-5.

102. Schiöler L, Söderberg M, Rosengren A, Järvholm B, Torén K. Psychosocial work environment and risk of ischemic stroke and coronary heart disease: a prospective longitudinal study of 75236 construction workers. Scand J Work Environ Health. 2015;41(3): 280-7. https://doi.org/10.5271/sjweh.3491.

103. Kershaw KN, Lane-Cordova AD, Carnethon MR, Tindle HA, Liu $\mathrm{K}$. Chronic stress and endothelial dysfunction: the multi-ethnic study of atherosclerosis (MESA). Am J Hypertens. 2017;30(1): 75-80. https://doi.org/10.1093/ajh/hpw103.

104. Chumaeva N, Hintsanen M, Pulkki-Råback L, Jokela M, Juonala M, Lehtimäki T, et al. Interleukin-6 gene polymorphism, chronic stress and atherosclerosis: interleukin-6-174G $>$ C polymorphism, chronic stress and risk of early atherosclerosis in the cardiovascular risk in young Finns study. J Psychosom Res. 2014;76(4):3338. https://doi.org/10.1016/j.jpsychores.2014.01.007.

105. Yao BC, Meng LB, Hao ML, Zhang YM, Gong T, Guo ZG. Chronic stress: a critical risk factor for atherosclerosis. J Int Med Res. 2019;47(4):1429-40. https://doi.org/10.1177/ 0300060519826820 .

106. Ushakov AV, Ivanchenko VS, Gagarina AA. Psychological stress in pathogenesis of essential hypertension. Curr Hypertens Rev. $2016 ; 12$ (3):203-14. https://doi.org/10.2174/ 1573402112666161230121622 .

107. Puzserova A, Bernatova I. Blood pressure regulation in stress: focus on nitric oxide-dependent mechanisms. Physiol Res. 2016;65(Suppl 3):S309-S42. https://doi.org/10.33549/ physiolres.933442.

108. Lupien SJ, Juster RP, Raymond C, Marin MF. The effects of chronic stress on the human brain: from neurotoxicity, to vulnerability, to opportunity. Front Neuroendocrinol. 2018;49: 91-105. https://doi.org/10.1016/j.yfrne.2018.02.001 Excellent review of the long-term physiological effects of chronic stress on brain heatlh.

109. Joëls M, de Kloet ER. 30 years of the mineralocorticoid receptor: the brain mineralocorticoid receptor: a saga in three episodes. J Endocrinol. 2017;234(1):T49-66. https://doi.org/10.1530/JOE16-0660.

110. McEwen BS, Weiss JM, Schwartz LS. Selective retention of corticosterone by limbic structures in rat brain. Nature. 1968;220(5170):911-2. https://doi.org/10.1038/220911a0.

111. Borcel E, Pérez-Alvarez L, Herrero AI, Brionne T, Varea E, Berezin V, et al. Chronic stress in adulthood followed by intermittent stress impairs spatial memory and the survival of newborn hippocampal cells in aging animals: prevention by FGL, a peptide mimetic of neural cell adhesion molecule. Behav Pharmacol. 2008;19(1):41-9. https://doi.org/10.1097/FBP. 0b013e3282f3fca9.

112. Lupien SJ, de Leon M, de Santi S, Convit A, Tarshish C, Nair NP, et al. Cortisol levels during human aging predict hippocampal atrophy and memory deficits. Nat Neurosci. 1998;1(1):69-73. https://doi.org/10.1038/271.

113. Zalachoras I, Houtman R, Meijer OC. Understanding stresseffects in the brain via transcriptional signal transduction pathways. Neuroscience. 2013;242:97-109. https://doi.org/10.1016/j. neuroscience.2013.03.038.

114. Chen DY, Bambah-Mukku D, Pollonini G, Alberini CM. Glucocorticoid receptors recruit the CaMKII $\alpha$-BDNF-CREB pathways to mediate memory consolidation. Nat Neurosci. 2012;15(12):1707-14. https://doi.org/10.1038/nn.3266.

115. Finsterwald C, Alberini CM. Stress and glucocorticoid receptordependent mechanisms in long-term memory: from adaptive responses to psychopathologies. Neurobiol Learn Mem. 2014;112: 17-29. https://doi.org/10.1016/j.nlm.2013.09.017.

116. Abercrombie HC, Speck NS, Monticelli RM. Endogenous cortisol elevations are related to memory facilitation only in individuals who are emotionally aroused. Psychoneuroendocrinology. 2006;31(2):187-96. https://doi.org/10.1016/j.psyneuen.2005.06. 008.

117. Salehi B, Cordero MI, Sandi C. Learning under stress: the inverted-U-shape function revisited. Learn Mem. 2010;17(10): 522-30. https://doi.org/10.1101/lm.1914110.

118. Guan WJ, Liang WH, Zhao Y, Liang HR, Chen ZS, Li YM, et al. Comorbidity and its impact on 1590 patients with COVID-19 in China: a nationwide analysis. Eur Respir J. 2020;55(5):2000547. https://doi.org/10.1183/13993003.00547-2020.

119. Ruan Q, Yang K, Wang W, Jiang L, Song J. Clinical predictors of mortality due to COVID-19 based on an analysis of data of 150 patients from Wuhan. China Intensive Care Med. 2020. https:// doi.org/10.1007/s00134-020-05991-x.

120. Sardu C, Gambardella J, Morelli MB, Wang X, Marfella R, Santulli G. Hypertension, thrombosis, kidney failure, and diabetes: is COVID-19 an endothelial disease? A comprehensive evaluation of clinical and basic evidence. J Clin Med. 2020;9(5):1417. https://doi.org/10.3390/jcm9051417.

121. Guan WJ, Ni ZY, Hu Y, Liang WH, Ou CQ, He JX, et al. Clinical characteristics of coronavirus disease 2019 in China. N Engl J Med. 2020. https://doi.org/10.1056/NEJMoa2002032.

122. Hoffmann M, Kleine-Weber H, Schroeder S, Krüger N, Herrler T, Erichsen S, et al. SARS-CoV-2 cell entry depends on ACE2 and TMPRSS 2 and is blocked by a clinically proven protease inhibitor. Cell. 2020. https://doi.org/10.1016/j.cell.2020.02.052.

123. Mehta P, McAuley DF, Brown M, Sanchez E, Tattersall RS, Manson JJ, et al. COVID-19: consider cytokine storm syndromes and immunosuppression. Lancet. 2020;395(10229):1033-4. https://doi.org/10.1016/S0140-6736(20)30628-0. 
124. Huentelman MJ, Zubcevic J, Hernández Prada JA, Xiao X, Dimitrov DS, Raizada MK, et al. Structure-based discovery of a novel angiotensin-converting enzyme 2 inhibitor. Hypertension. 2004;44(6):903-6. https://doi.org/10.1161/01.HYP.0000146120. 29648.36.

125. Fan HH, Wang LQ, Liu WL, An XP, Liu ZD, He XQ, et al. Repurposing of clinically approved drugs for treatment of coronavirus disease 2019 in a 2019-novel coronavirus (2019-nCoV) related coronavirus model. Chin Med J. 2020;133:1051-6. https:// doi.org/10.1097/CM9.0000000000000797.

126. Morse JS, Lalonde T, Xu S, Liu WR. Learning from the past: possible urgent prevention and treatment options for severe acute respiratory infections caused by $2019-\mathrm{nCoV}$. Chembiochem. 2020;21(5):730-8. https://doi.org/10.1002/cbic.202000047.

127. Santos RA, Ferreira AJ, Verano-Braga T, Bader M. Angiotensinconverting enzyme 2, angiotensin-(1-7) and Mas: new players of the renin-angiotensin system. J Endocrinol. 2013;216(2):R1-R17. https://doi.org/10.1530/JOE-12-0341.

128. Ferrario CM. Angiotensin-converting enzyme 2 and angiotensin(1-7): an evolving story in cardiovascular regulation. Hypertension. 2006;47(3):515-21. https://doi.org/10.1161/01. HYP.0000196268.08909.fb.

129. Raizada MK, Ferreira AJ. ACE2: a new target for cardiovascular disease therapeutics. J Cardiovasc Pharmacol. 2007;50(2):112-9. https://doi.org/10.1097/FJC.0b013e3180986219.

130. Vickers C, Hales P, Kaushik V, Dick L, Gavin J, Tang J, et al. Hydrolysis of biological peptides by human angiotensinconverting enzyme-related carboxypeptidase. J Biol Chem. 2002;277(17):14838-43. https://doi.org/10.1074/jbc. M200581200.

131. Lazartigues E, Feng Y, Lavoie JL. The two fACEs of the tissue renin-angiotensin systems: implication in cardiovascular diseases. Curr Pharm Des. 2007;13(12):1231-45.

132. Schram MT, Euser SM, de Craen AJ, Witteman JC, Frölich M, Hofman A, et al. Systemic markers of inflammation and cognitive decline in old age. J Am Geriatr Soc. 2007;55(5):708-16. https:// doi.org/10.1111/j.1532-5415.2007.01159.x.

133. Mao L, Wang M, Chen S, He Q, Chang J. et al. Neurological manifestations of hospitalized patients with COVID-19 in Wuhan, China: a retrospective case series. medRxiv. 2020.

134. Bader M. ACE2, angiotensin-(1-7), and Mas: the other side of the coin. Pflugers Arch. 2013;465(1):79-85. https://doi.org/10.1007/ s00424-012-1120-0.

135. Baig AM, Khaleeq A, Ali U, Syeda H. Evidence of the COVID-19 virus targeting the CNS: tissue distribution, host-virus interaction, and proposed neurotropic mechanisms. ACS Chem Neurosci. 2020;11(7):995-8. https://doi.org/10.1021/acschemneuro. 0c00122.

136. Benjamin EJ, Muntner P, Alonso A, Bittencourt MS, Callaway CW, Carson AP, et al. Heart disease and stroke statistics-2019 update: a report from the American Heart Association. Circulation. 2019;139(10):e56-e528. https://doi.org/10.1161/ CIR.0000000000000659.

137. Guzik TJ, Touyz RM. Oxidative stress, inflammation, and vascular aging in hypertension. Hypertension. 2017;70(4):660-7. https://doi.org/10.1161/HYPERTENSIONAHA.117.07802.

138. Petrie JR, Guzik TJ, Touyz RM. Diabetes, hypertension, and cardiovascular disease: clinical insights and vascular mechanisms. Can J Cardiol. 2018;34(5):575-84. https://doi.org/10.1016/j.cjca. 2017.12.005.

139. Uryga AK, Bennett MR. Ageing induced vascular smooth muscle cell senescence in atherosclerosis. J Physiol. 2016;594(8):211524. https://doi.org/10.1113/JP270923.

140. Mitchell GF, Hwang SJ, Vasan RS, Larson MG, Pencina MJ, Hamburg NM, et al. Arterial stiffness and cardiovascular events: the Framingham Heart Study. Circulation. 2010;121(4):505-11. https://doi.org/10.1161/CIRCULATIONAHA.109.886655.

141. Abbas M, Jesel L, Auger C, Amoura L, Messas N, Manin G, et al. Endothelial microparticles from acute coronary syndrome patients induce premature coronary artery endothelial cell aging and thrombogenicity: role of the Ang II/AT1 receptor/NADPH oxidase-mediated activation of MAPKs and PI3-kinase pathways. Circulation. 2017;135(3):280-96. https://doi.org/10.1161/ CIRCULATIONAHA.116.017513.

142. Sowers JR. Insulin and insulin-like growth factor in normal and pathological cardiovascular physiology. Hypertension. 1997;29(3):691-9. https://doi.org/10.1161/01.hyp.29.3.691.

143. Pal PB, Sonowal H, Shukla K, Srivastava SK, Ramana KV. Aldose reductase mediates NLRP3 Inflammasome-initiated innate immune response in hyperglycemia-induced Thp 1 monocytes and male mice. Endocrinology. 2017;158(10):3661-75. https://doi. org/10.1210/en.2017-00294.

144. Buford TW. Hypertension and aging. Ageing Res Rev. 2016;26: 96-111. https://doi.org/10.1016/j.arr.2016.01.007.

145. Wadley AJ, Veldhuijzen van Zanten JJ, Aldred S. The interactions of oxidative stress and inflammation with vascular dysfunction in ageing: the vascular health triad. Age (Dordr). 2013;35(3):70518. https://doi.org/10.1007/s11357-012-9402-1.

146. Norling AM, Gerstenecker AT, Buford TW, Khan B, Oparil S, Lazar RM. The role of exercise in the reversal of IGF-1 deficiencies in microvascular rarefaction and hypertension. Geroscience. 2020;42(1):141-58. https://doi.org/10.1007/s11357-019-001392.

147. Gould IG, Tsai P, Kleinfeld D, Linninger A. The capillary bed offers the largest hemodynamic resistance to the cortical blood supply. J Cereb Blood Flow Metab. 2017;37(1):52-68. https:// doi.org/10.1177/0271678X16671146.

148. Purkayastha S, Fadar O, Mehregan A, Salat DH, Moscufo N, Meier DS, et al. Impaired cerebrovascular hemodynamics are associated with cerebral white matter damage. J Cereb Blood Flow Metab. 2014;34(2):228-34. https://doi.org/10.1038/jcbfm.2013. 180.

149. Ciuffetti G, Pasqualini L, Pirro M, Lombardini R, De Sio M, Schillaci G, et al. Blood rheology in men with essential hypertension and capillary rarefaction. J Hum Hypertens. 2002;16(8):5337. https://doi.org/10.1038/sj.jhh.1001454.

150. Ciuffetti G, Schillaci G, Innocente S, Lombardini R, Pasqualini L, Notaristefano S, et al. Capillary rarefaction and abnormal cardiovascular reactivity in hypertension. J Hypertens. 2003;21(12): 2297-303. https://doi.org/10.1097/00004872-200312000-00018.

151. De Geyter D, De Smedt A, Stoop W, De Keyser J, Kooijman R. Central IGF-I receptors in the brain are instrumental to neuroprotection by systemically injected IGF-I in a rat model for ischemic stroke. CNS Neurosci Ther. 2016;22(7):611-6. https://doi.org/10. $1111 /$ cns. 12550.

152. Hunt KJ, Lukanova A, Rinaldi S, Lundin E, Norat T, Palmqvist R, et al. A potential inverse association between insulin-like growth factor I and hypertension in a cross-sectional study. Ann Epidemiol. 2006;16(7):563-71. https://doi.org/10.1016/j. annepidem.2005.10.007.

153. Yao J, Brinton RD. Targeting mitochondrial bioenergetics for Alzheimer's prevention and treatment. Curr Pharm Des. 2011;17(31):3474-9. https://doi.org/10.2174/ 138161211798072517.

154. Graham SH, Liu H. Life and death in the trash heap: the ubiquitin proteasome pathway and UCHL1 in brain aging, neurodegenerative disease and cerebral ischemia. Ageing Res Rev. 2017;34:30 8. https://doi.org/10.1016/j.arr.2016.09.011.

155. Soldan A, Moghekar A, Walker KA, Pettigrew C, Hou X, Lu H, et al. Resting-state functional connectivity is associated with cerebrospinal fluid levels of the synaptic protein NPTX2 in non- 
demented older adults. Front Aging Neurosci. 2019;11:132. https://doi.org/10.3389/fnagi.2019.00132.

156. Mattson MP, Arumugam TV. Hallmarks of brain aging: adaptive and pathological modification by metabolic states. Cell Metab. 2018;27(6):1176-99. https://doi.org/10.1016/j.cmet.2018.05.011.

157. Venturelli M, Pedrinolla A, Boscolo Galazzo I, Fonte C, Smania $\mathrm{N}$, Tamburin S, et al. Impact of nitric oxide bioavailability on the progressive cerebral and peripheral circulatory impairments during aging and Alzheimer's disease. Front Physiol. 2018;9:-169. https://doi.org/10.3389/fphys.2018.00169 These authours employ MRI to assess to relationship between NO bioavailability, cerebral perfusion and the presence or absence of cognitive impairment or Alzheimer's disease.

158. Rea IM, Gibson DS, McGilligan V, McNerlan SE, Alexander HD, Ross OA. Age and age-related diseases: role of inflammation triggers and cytokines. Front Immunol. 2018;9:586. https://doi.org/ 10.3389/fimmu.2018.00586

159.• Newcombe EA, Camats-Perna J, Silva ML, Valmas N, Huat TJ, Medeiros R. Inflammation: the link between comorbidities, genetics, and Alzheimer's disease. J Neuroinflammation. 2018;15(1): 276. https://doi.org/10.1186/s12974-018-1313-3 Excellent review detailing the effects of chronic inflammation and related mechanisms on brain health and disease.

160. Athilingam P, Moynihan J, Chen L, D'Aoust R, Groer M, Kip K. Elevated levels of interleukin 6 and $\mathrm{C}$-reactive protein associated with cognitive impairment in heart failure. Congest Heart Fail. 2013;19(2):92-8. https://doi.org/10.1111/chf.12007.

161. Kure CE, Rosenfeldt FL, Scholey AB, Pipingas A, Kaye DM, Bergin PJ, et al. Relationships among cognitive function and cerebral blood flow, oxidative stress, and inflammation in older heart failure patients. J Card Fail. 2016;22(7):548-59. https://doi. org/10.1016/j.cardfail.2016.03.006.

162. Mann DL. Innate immunity and the failing heart: the cytokine hypothesis revisited. Circ Res. 2015;116(7):1254-68. https://doi. org/10.1161/CIRCRESAHA.116.302317.

163. Teunissen CE, van Boxtel MP, Bosma H, Bosmans E, Delanghe J, De Bruijn $\mathrm{C}$, et al. Inflammation markers in relation to cognition in a healthy aging population. J Neuroimmunol. 2003;134(1-2): 142-50. https://doi.org/10.1016/s0165-5728(02)00398-3.

164. Heringa SM, van den Berg E, Reijmer YD, Nijpels G, Stehouwer $\mathrm{CD}$, Schalkwijk CG, et al. Markers of low-grade inflammation and endothelial dysfunction are related to reduced information processing speed and executive functioning in an older population the Hoorn study. Psychoneuroendocrinology. 2014;40:108-18. https://doi.org/10.1016/j.psyneuen.2013.11.011.

165. Bettcher BM, Watson CL, Walsh CM, Lobach IV, Neuhaus J, Miller JW, et al. Interleukin-6, age, and corpus callosum integrity. PLoS One. 2014;9(9):e106521. https://doi.org/10.1371/journal. pone.0106521.

166. Nowak EC, Weaver CT, Turner H, Begum-Haque S, Becher B, Schreiner B, et al. IL-9 as a mediator of Th17-driven inflammatory disease. J Exp Med. 2009;206(8):1653-60. https://doi.org/10. 1084/jem.20090246.

Publisher's Note Springer Nature remains neutral with regard to jurisdictional claims in published maps and institutional affiliations. 